\title{
Perception about COVID-19 among Dental Students of a Tertiary Care Dental Hospital, Bangalore - A Cross-Sectional Survey
}

\author{
Nigy Johnson ${ }^{1}$, Shweta Somasundara Y2, Padma K. Bhat ${ }^{3}$, Santhosh Kumar', \\ Nayana $\mathrm{M}^{5}$, Jayachandra M.Y.6, Karishma S. Halageri ${ }^{7}$, Subodh Kumar ${ }^{8}$ \\ 1,2,3,4,5, 6, 7, 8 Department of Public Health Dentistry, Rajarajeswari \\ Dental College and Hospital, Bangalore, Karnataka, India.
}

\section{ABSTRACT}

\section{BACKGROUND}

During the lockdown period of COVID-19 pandemic, dental colleges in Bangalore, India, had switched to online dental education and when the cases started to decline, the dental colleges finally welcomed students on campus in November 2020 following the Government directions. Majority of the dental procedures produce droplets and aerosols in a dental practice. In this context, the standard protective measures are not enough in the daily dental practice during this pandemic. Dental professionals, students in particular should be aware of the main symptoms of COVID-19, its mode of transmission and precautions to be adopted in the dental practice so as to break the chain of infection. The purpose of the study was to investigate the perception regarding COVID-19 among the dental students of a dental teaching institution in Bangalore city.

\section{METHODS}

An online questionnaire was created to assess the perception about COVID-19 among dental students. Total enumeration method was followed, and undergraduates, interns and post graduate students of a tertiary care dental hospital participated in the online survey. chi-square goodness of fit test was used to compare the differences in the distribution of respondents and independent chi- square test was used to do the comparison in the difference of responses towards the study questionnaire between the students studying in different undergraduate years; with level of significance set at $\mathrm{P}<0.05$.

\section{RESULTS}

About 380 dental students participated in the online survey; correct response rate was slightly higher among clinical dental students than pre-clinical students. Educational and training programmes related to COVID-19, infection control and practices were implemented at the institution for the dental professionals in the academic level.

\section{CONCLUSIONS}

The perception about COVID-19 among pre-clinical dental students were slightly lower than the clinical students.

\section{KEY WORDS}

Clinical, COVID-19, Dental Students, Pre-Clinical
Corresponding Author: Dr. Nigy Johnson, Department of Public Health Dentistry, Rajarajeswari Dental College and Hospital, Bangalore, Karnataka, India. E-mail: drnigy@gmail.com

DOI: $10.14260 /$ jemds/2021/405

How to Cite This Article:

Johnson N, Somasundara YS, Bhat PK, et al. Perception about covid-19 among dental students of a tertiary care dental hospital, Bangalore - a cross-sectional survey. J Evolution Med Dent Sci 2021;10(27):19711978, DOI: 10.14260/jemds/2021/405

Submission 01-03-2021,

Peer Review 06-05-2021,

Acceptance 12-05-2021,

Published 05-07-2021.

Copyright (C) 2021 Nigy Johnson et al. This is an open access article distributed under Creative Commons Attribution License [Attribution 4.0 International (CC BY 4.0)] 


\section{BACKGROUND}

In the current situation of COVID-19 pandemic dental professionals should be familiar with the mode of transmission of the virus, identifying the patients with symptoms and to take necessary protective measures to break the chain of infection while in the dental practice. ${ }^{1}$ In a recent study, COVID-19 was found in the saliva ${ }^{2}$ of infected patients and this situation is alarming for the dental professionals as most of the dental procedures are aerosol producing which in turn lead to direct and indirect disease transmission. Hence, it is crucial for dentists to procure preventive strategies to avoid the COVID-19 infection by focusing on patient placement, hand hygiene and having Personal Protective Equipment (PPE). Due to the unique characteristics of dental procedures, the standard protective measures in daily clinical work are not effective enough to prevent the spread of COVID-19, especially when patients are in the incubation period, and are unaware of them being infected or choose to conceal their infection.

Thus, this study intended to investigate the perception regarding COVID-19 among dental students in a tertiary care dental institution in Bangalore city. Before the institution closed for the lockdown a screening and triage form was issued and undergraduates were briefed by the faculty of Public Health Dentistry on the precautions to be taken. As part of preparedness of dental students for patient care once the lockdown ended, we wished to identify the gaps in the knowledge amongst the undergraduate and postgraduate students of our institution so that they can be further updated to deal with patient care during the year of the COVID-19 pandemic. Hence this study was carried out online to assess the perception about COVID-19 among the dental students.

The findings helped the institution to organize the necessary educational programs for the students in order to provide up-to-date information and deliver the best practice to control the Severe Acute Respiratory Syndrome Corona Virus 2 (SARS-CoV-2) disease in the Dental scenario.

\section{METHODS}

A descriptive cross-sectional online survey was carried out using Google forms after obtaining ethical clearance from the Institutional Review Board (RRDCHET/06PHD/2020). The informed consent was obtained from the respondents; data was collected from April 2020 to May 2020 from all the undergraduate dental students, interns and postgraduate students of a tertiary care dental institution in Bangalore city. A pilot survey was carried out among 20 dental students of the tertiary care dental institution, who were excluded in the final survey, to test the online questionnaire for comprehensibility and acceptance.

Data collection was done maintaining anonymity and confidentiality by not recording the names of the participants on the questionnaire. A pre-tested questionnaire was used to collect the data from the participants. Questions from previously published literature were included in the questionnaire. Face validity was established by a consultative process with experts. The questionnaire consisted of 28 closed-ended questions which included 13 knowledge, 5 attitude and 7 practice questions assessing the perception about COVID-19 among dental students. Total enumeration method was followed and students of a tertiary care dental college were invited to participate in the online survey. Reminders to encourage participation were given after 3 working days, to improve response rate. Total number of the participants was estimated as 350 .

\section{Statistical Analysis}

Statistical Package for Social Sciences [SPSS] for Windows Version 22.0 Released 2013. Armonk, NY: IBM Corp., was used to perform statistical analyses. Comparison of distribution of responses for questionnaire among study participants with responses for study questionnaire between Pre-clinical (1 $1^{\text {st }}$ and $2^{\text {nd }}$ year BDS students) and Clinical ( $3^{\text {rd }}$ and $4^{\text {th }}$ year BDS students, interns and PG students) work exposure participants using chi square Test was done, with a statistical significance of $\mathrm{P}<0.05$.

\section{RESULTS}

A total of 380 dental students participated in the study, among them males were 78 (20.5\%) and females were 302 (79.5\%). Majority of participants were of the age group 18 - 25 years $(91.6 \%, \mathrm{~N}=348)$ and about $31.3 \%(\mathrm{~N}=119)$ of them were $1^{\text {st }}$ year BDS followed by $2^{\text {nd }}$ year BDS $(28.2 \%, \mathrm{~N}=107) .1^{\text {st }}(31.3$ $\%, N=119) \& 2^{\text {nd }}(28.2 \%, N=107)$ year BDS students were categorized as having only pre-clinical work experience and other participants $\left(3^{\text {rd }}\right.$ year $-14.2 \%, \mathrm{~N}=54 ; 4^{\text {th }}$ year $-10.5 \%$, $\mathrm{N}=40$; Interns $-6.3 \%, \mathrm{~N}=24$; PGs $-9.5 \%, \mathrm{~N}=36$ ) with clinical exposure. In that aspect about 226 (59.5\%) of the dental students were from pre-clinical and about 154 (40.5\%) of them from clinical work exposure (Table 1).

\begin{tabular}{|cccc|}
\hline Variable & Category & N & $\%$ \\
Area of Work Exposure & Pre-clinical & 226 & $59.5 \%$ \\
& Clinical & 154 & $40.5 \%$ \\
\hline \multicolumn{3}{|c|}{ Table 1. Distribution of Study Participants } \\
Based on the Area of Work Exposure \\
\hline
\end{tabular}

Majority of the dental students (96.3\%, N = 366) responded that COVID-19 was spread through respiratory droplets, aerosol, direct contact, feco- oral route and fomites (Table 2); includes $98.2 \%(\mathrm{~N}=222)$ of pre- clinical students and $93.5 \%(\mathrm{~N}=154)$ of clinical students (P - 0.005) (Table 3$)$.

About $49.2 \%(\mathrm{~N}=187)$ participants did not know that the etiologic agent of Covid-19, SARS-CoV-2 is different from SARS-CoV, but it has the same host receptor (Table 2); $55.8 \%$ $(\mathrm{N}=126)$ were the pre-clinical and $39.6 \%(\mathrm{~N}=61)$ were the clinical students (P - 0.008) (Table 3.).

About $68.7 \%(\mathrm{~N}=261)$ of the dental students were aware that antiseptic mouthwashes could only reduce the viral load whereas it could not be eliminated in the saliva (Table 2) (Graph 1); included $64.2 \%(\mathrm{~N}=145)$ of the pre-clinical and $75.3 \%(\mathrm{~N}=116)$ of the clinical students ( $\mathrm{P}-0.04)$ (Table 3$)$.

A relatively greater number of clinical students $(29.9 \%, \mathrm{~N}$ $=46)$ than the preclinical students $(23 \%, \mathrm{~N}=52)$ responded that COVID-19 was not fatal than NIPAH virus infection $(\mathrm{P}$ 0.002) (Table 3). Majority of the participants (82.6\%, N = 314) 
(Table 2) and majority of the preclinical (85 \%, N = 192) and clinical students (79.2 \%, N = 122) (Table 3) (Graph 3) (P 0.04) had the attitude that India could win the battle against the SARS-CoV-2. Majority of the dental students $(86.1 \%, \mathrm{~N}=$ 327) responded that all surfaces, chairs, magazines, doors of the clinic and waiting area that came into contact with dentists and patients were considered "potentially infected" (Table 2), among them $81 \%(\mathrm{~N}=183)$ were pre-clinical and $93.5 \%(\mathrm{~N}=$ 144) were clinical students $(\mathrm{P}<0.001$ ) (Table 3$)$. About 50.8 $\%(\mathrm{~N}=193)$ of them responded that the virus remained longer on steel instruments (Table 2); $45.6 \%(\mathrm{~N}=103)$ were preclinical and $58.4 \%(\mathrm{~N}=90)$ were the clinical students $(\mathrm{P}$ 0.01) (Table 3).

\begin{tabular}{|c|c|c|c|c|c|}
\hline Questions & Responses & $\mathbf{N}$ & $\%$ & $\chi^{2}$ Value & P-Value \\
\hline \multirow{3}{*}{$\begin{array}{c}\text { COVID-19 is spread through respiratory droplets, aerosol, direct contact, feco- } \\
\text { oral route and fomites }\end{array}$} & True & 366 & $96.3 \%$ & \multirow{3}{*}{678.716} & \multirow{3}{*}{$<0.001^{*}$} \\
\hline & False & 12 & $3.2 \%$ & & \\
\hline & Don't know & 2 & $0.5 \%$ & & \\
\hline \multirow{3}{*}{ COVID-19 may be spread through the airborne route. } & True & 237 & $62.4 \%$ & \multirow{3}{*}{167.563} & \multirow{3}{*}{$<0.001^{*}$} \\
\hline & False & 110 & $28.9 \%$ & & \\
\hline & Don't know & 33 & $8.7 \%$ & & \\
\hline & True & 172 & $45.3 \%$ & & \\
\hline The etiologic agent of Covid19, SARS-CoV-2 is different from SARS-Co-V, with & False & 21 & $5.5 \%$ & 133.111 & $<0.001^{*}$ \\
\hline & Don't know & 187 & $49.2 \%$ & & \\
\hline & True & 342 & $90.0 \%$ & & \\
\hline & Don't know & 12 & $3.2 \%$ & & \\
\hline & True & 343 & $90.3 \%$ & & \\
\hline Individuals infected with CUVID-19 can spread the disease even in the pre- & False & 10 & $2.6 \%$ & 555.353 & $<0.001^{*}$ \\
\hline & Don't know & 27 & $7.1 \%$ & & \\
\hline & True & 327 & $86.1 \%$ & & \\
\hline into contact with dentist and, natients must be considered "potentially infected" & False & 20 & $5.3 \%$ & 475.932 & $<0.001 *$ \\
\hline & Don't know & 33 & $8.7 \%$ & & \\
\hline & True & 193 & $50.8 \%$ & & \\
\hline The virus remains longer on steel instruments & False & 47 & $12.4 \%$ & 86.247 & $<0.001^{*}$ \\
\hline & Don't know & 140 & $36.8 \%$ & & \\
\hline Dentists are most exposed to the risk of being affected by COVID-19, much more & False & 30 & $7.9 \%$ & 485.121 & $<0.001^{*}$ \\
\hline & Don't know & 21 & $5.5 \%$ & & \\
\hline & True & 153 & $40.3 \%$ & & \\
\hline The SARS-Cov-2 can survive hands, surfaces or objects when came in contact with & False & 88 & $23.2 \%$ & 18.479 & $<0.001^{*}$ \\
\hline & Don't know & 139 & $36.5 \%$ & & \\
\hline & True & 261 & $68.7 \%$ & & \\
\hline Rinses with antiseptic mouthwashes can only reduce the viral load but it cannot & False & 45 & $11.8 \%$ & 217.016 & $<0.001^{*}$ \\
\hline & Don't know & 74 & $19.5 \%$ & & \\
\hline & True & 345 & $90.8 \%$ & & \\
\hline Minimum time taken for hand washing is $20 \mathrm{sec}$. & False & 26 & $6.8 \%$ & 565.647 & $<0.001^{*}$ \\
\hline & Don't know & 9 & $2.4 \%$ & & \\
\hline & $20 \%$ & 31 & $8.2 \%$ & & \\
\hline Alcohol-based hand sanitizer used in hand hygiene contains -------- alcohol. & $33-40 \%$ & 68 & $17.9 \%$ & 287.468 & $<0.001^{*}$ \\
\hline & $60-95 \%$ & 281 & $73.9 \%$ & & \\
\hline & True & 362 & $95.3 \%$ & & \\
\hline $\begin{array}{l}\text { Current treatment for COVID-19 includes isolation, early symptomatic, and } \\
\text { supportive treatment. }\end{array}$ & False & 4 & $1.1 \%$ & 656.232 & $<0.001^{*}$ \\
\hline & Don't know & 14 & $3.7 \%$ & & \\
\hline & Agree & 369 & $97.1 \%$ & & \\
\hline COVID-19 can affect anyone regardless of their age, race or ethnicity. & Disagree & 6 & $1.6 \%$ & 695.437 & $<0.001^{*}$ \\
\hline & Don't know & 5 & $1.3 \%$ & & \\
\hline & Agree & 197 & $51.8 \%$ & & \\
\hline COVID-19 is fatal than NIPAH virus infection & False & 98 & $25.8 \%$ & 27.984 & $<0.001^{*}$ \\
\hline & Don't know & 107 & $28.2 \%$ & & \\
\hline & Agree & 314 & $82.6 \%$ & & \\
\hline India can win the battle against the COVID- 19. & Disagree & 7 & $1.8 \%$ & 426.258 & $<0.001^{*}$ \\
\hline & Don't know & 59 & $15.5 \%$ & & \\
\hline & Agree & 368 & $96.8 \%$ & & \\
\hline $\begin{array}{l}\text { As an oral health professional, we have a responsibility to give awareness about } \\
\text { COVID-19 to avoid social stigma regarding the same }\end{array}$ & Disagree & 3 & $0.8 \%$ & 689.847 & $<0.001^{*}$ \\
\hline & Don't Know & 9 & $2.4 \%$ & & \\
\hline & Yes & 314 & $82.6 \%$ & & \\
\hline Is a preoperative antimicrobial mouth rinse recommended for a dental practice? & No & 4 & $1.1 \%$ & 428.863 & $<0.001^{*}$ \\
\hline & Don't Know & 62 & $16.3 \%$ & & \\
\hline & $0.2 \%$ Povidone & 14 & $3.7 \%$ & & \\
\hline & $1 \% \mathrm{H} 202$ & 23 & $6.1 \%$ & & \\
\hline If yes, which one is currently recommended for use? & Chlorhexidine & 201 & $52.9 \%$ & 265.158 & $<0.001^{*}$ \\
\hline & Either $\mathrm{a}$ or $\mathrm{b}$ & 142 & $37.4 \%$ & & \\
\hline & Yes & 240 & $63.2 \%$ & & \\
\hline Donning PPE: gloves, mask / respirator, goggles / face shield, gown. & No & 84 & $22.1 \%$ & 155.200 & $<0.001^{*}$ \\
\hline & Don't Know & 56 & $14.7 \%$ & & \\
\hline & True & 161 & $42.4 \%$ & & \\
\hline Doffing PPE: Gown, Gloves, Mask / respirator, Goggles / Face shield. & False & 131 & $34.5 \%$ & 21.258 & $<0.001^{*}$ \\
\hline & Don't Know & 88 & $23.2 \%$ & & \\
\hline & Yes & 153 & $40.3 \%$ & & \\
\hline The use or hana instrumentation, dental dam and nign-speed suction can & No & 81 & $21.3 \%$ & 24.889 & $<0.001^{*}$ \\
\hline & Don't Know & 146 & $38.4 \%$ & & \\
\hline & Yes & 227 & $59.7 \%$ & & \\
\hline Screening for dental emergencies using Tele-dentistry or other methods & No & 19 & $5.0 \%$ & 171.416 & $<0.001^{*}$ \\
\hline & Don't Know & 134 & $35.3 \%$ & & \\
\hline & Yes & 212 & $55.8 \%$ & & \\
\hline If a patient reports with a travel history and symptoms of COVID-19, will you treat & No & 96 & $25.3 \%$ & 88.505 & $<0.001^{*}$ \\
\hline & Don't Know & 72 & $18.9 \%$ & & \\
\hline & Yes & 361 & $95.0 \%$ & & \\
\hline Will you report suspected cases to the concerned staff and Head of Institution? & No & 3 & $0.8 \%$ & 650.942 & $<0.001^{*}$ \\
\hline & Don't Know & 16 & $4.2 \%$ & & \\
\hline
\end{tabular}




\begin{tabular}{|c|c|c|c|c|c|c|c|}
\hline \multirow{2}{*}{ Questions } & \multirow{2}{*}{ Category } & \multicolumn{2}{|c|}{ Pre-clinical } & \multicolumn{2}{|c|}{ Clinical } & \multirow{2}{*}{$\chi^{2}$ Value } & \\
\hline & & $\mathbf{n}$ & $\%$ & $\mathbf{n}$ & $\%$ & & P-Value \\
\hline & True & 222 & $98.2 \%$ & 144 & $93.5 \%$ & & \\
\hline COVID-19 is spread through respiratory droplets, & False & 2 & $0.9 \%$ & 10 & $6.5 \%$ & 10.698 & $0.005^{*}$ \\
\hline & Don't know & 2 & $0.9 \%$ & 0 & $0.0 \%$ & & \\
\hline & True & 135 & $59.7 \%$ & 102 & $66.2 \%$ & & \\
\hline COVID-19 may be spread through the airborne route. & False & 70 & $31.0 \%$ & 40 & $26.0 \%$ & 1.648 & 0.44 \\
\hline & Don't know & 21 & $9.3 \%$ & 12 & $7.8 \%$ & & \\
\hline & True & 89 & $39.4 \%$ & 83 & $53.9 \%$ & & \\
\hline I he etroiogic a from SAR -COV with & False & 11 & $4.9 \%$ & 10 & $6.5 \%$ & 9.551 & $0.008^{*}$ \\
\hline & Don't know & 126 & $55.8 \%$ & 61 & $39.6 \%$ & & \\
\hline & True & 202 & $89.4 \%$ & 140 & $90.9 \%$ & & \\
\hline Fever, fatigue, ary cough, myalgia- main symptoms of & False & 15 & $6.6 \%$ & 11 & $7.1 \%$ & 1.258 & 0.53 \\
\hline & Don't Know & 9 & $4.0 \%$ & 3 & $1.9 \%$ & & \\
\hline Individuals infected with COVID-19 may can spread & True & 200 & $88.5 \%$ & 143 & $92.9 \%$ & & \\
\hline the disease even in the pre-symptomatic stage & False & 5 & $2.2 \%$ & 5 & $3.2 \%$ & 4.319 & 0.12 \\
\hline including through saliva. & Don't know & 21 & $9.3 \%$ & 6 & $3.9 \%$ & & \\
\hline All surfaces, chairs, magazines, and doors of the clinic & True & 183 & $81.0 \%$ & 144 & $93.5 \%$ & & \\
\hline and waiting area that come into contact with dentist & False & 11 & $4.9 \%$ & 9 & $5.8 \%$ & 21.088 & $<0.001^{*}$ \\
\hline and patients must be considered "potentially infected." & Don't know & 32 & $14.2 \%$ & 1 & $0.6 \%$ & & \\
\hline & True & 103 & $45.6 \%$ & 90 & $58.4 \%$ & & \\
\hline The virus remains longer on steel instruments & False & 26 & $11.5 \%$ & 21 & $13.6 \%$ & 8.914 & $0.01 *$ \\
\hline & Don't know & 97 & $42.9 \%$ & 43 & $27.9 \%$ & & \\
\hline Dentists are most exposed to the risk of being affected & True & 190 & $84.1 \%$ & 139 & $90.3 \%$ & & \\
\hline by COVID-19, much more than other health & False & 20 & $8.8 \%$ & 10 & $6.5 \%$ & 3.484 & 0.18 \\
\hline professionals. & Don't know & 16 & $7.1 \%$ & 5 & $3.2 \%$ & & \\
\hline The SARS-CoV-2 can survive hands, surfaces or objects & True & 89 & $39.4 \%$ & 64 & $41.6 \%$ & & \\
\hline when came in contact even before 9 days with infected & False & 44 & $19.5 \%$ & 44 & $28.6 \%$ & 6.571 & $0.04 *$ \\
\hline saliva. & Don't know & 93 & $41.2 \%$ & 46 & $29.9 \%$ & & \\
\hline Rinses with antiseptic mouthwashes can only reduce & True & 145 & $64.2 \%$ & 116 & $75.3 \%$ & & \\
\hline the viral load whereas it cannot be eliminated in the & False & 33 & $14.6 \%$ & 12 & $7.8 \%$ & 6.141 & $0.04 *$ \\
\hline saliva. & Don't know & 48 & $21.2 \%$ & 26 & $16.9 \%$ & & \\
\hline & True & 203 & $89.8 \%$ & 142 & $92.2 \%$ & & \\
\hline Minimum time should be taken for hand washing is 20 & False & 16 & $7.1 \%$ & 10 & $6.5 \%$ & 1.354 & 0.51 \\
\hline & Don't know & 7 & $3.1 \%$ & 2 & $1.3 \%$ & & \\
\hline & $20 \%$ & 21 & $9.3 \%$ & 10 & $6.5 \%$ & & \\
\hline Alcohol-based hand sanitizer used in hand hygiene & $33-40 \%$ & 40 & $17.7 \%$ & 28 & $18.2 \%$ & 0.958 & 0.62 \\
\hline & $60-95 \%$ & 165 & $73.0 \%$ & 116 & $75.3 \%$ & & \\
\hline & True & 212 & $93.8 \%$ & 150 & $97.4 \%$ & & \\
\hline Current treatment for CUVID-19 include isolation, & False & 2 & $0.9 \%$ & 2 & $1.3 \%$ & 4.273 & 0.12 \\
\hline & Don't know & 12 & $5.3 \%$ & 2 & $1.3 \%$ & & \\
\hline & Agree & 219 & $96.9 \%$ & 150 & $97.4 \%$ & & \\
\hline COVID-19 can affect anyone regardless of their age, & Disagree & 4 & $1.8 \%$ & 2 & $1.3 \%$ & 0.132 & 0.94 \\
\hline & Don't know & 3 & $1.3 \%$ & 2 & $1.3 \%$ & & \\
\hline & Agree & 109 & $48.2 \%$ & 88 & $57.1 \%$ & & \\
\hline A Patient who has tested negative twice after having & Disagree & 80 & $35.4 \%$ & 52 & $33.8 \%$ & 5.091 & 0.08 \\
\hline & Don't know & 37 & $16.4 \%$ & 14 & $9.1 \%$ & & \\
\hline & True & 95 & $42.0 \%$ & 80 & $51.9 \%$ & & \\
\hline COVID-19 is fatal than NIPAH virus infection. & False & 52 & $23.0 \%$ & 46 & $29.9 \%$ & 12.778 & $0.002^{*}$ \\
\hline & Don't know & 79 & $35.0 \%$ & 28 & $18.2 \%$ & & \\
\hline & Agree & 192 & $85.0 \%$ & 122 & $79.2 \%$ & & \\
\hline India can win the battle against the COVID- 19. & Disagree & 1 & $0.4 \%$ & 6 & $3.9 \%$ & 6.602 & $0.04^{*}$ \\
\hline & Don't know & 33 & $14.6 \%$ & 26 & $16.9 \%$ & & \\
\hline As an oral health professional, we have a responsibility & Agree & 216 & $95.6 \%$ & 152 & $98.7 \%$ & & \\
\hline to give awareness about COVID-19 to avoid social & Disagree & 3 & $1.3 \%$ & 0 & $0.0 \%$ & 3.388 & 0.18 \\
\hline stigma regarding the same & Don't know & 7 & $3.1 \%$ & 2 & $1.3 \%$ & & \\
\hline & Yes & 168 & $74.34 \%$ & 146 & $94.8 \%$ & & \\
\hline Is a preoperative antimicrobial mouth rinse & No & 1 & $0.44 \%$ & 3 & $2 \%$ & 33.723 & $<0.001^{*}$ \\
\hline & Don't know & 57 & $25.22 \%$ & 5 & $3.2 \%$ & & \\
\hline & $0.2 \%$ povidone & 12 & $5.3 \%$ & 2 & $1.3 \%$ & & \\
\hline & $1 \% \mathrm{~h} 202$ & 17 & $7.5 \%$ & 6 & $3.9 \%$ & & \\
\hline If yes, which one is currently recommended for use? & Chlorhexidine & 93 & $41.2 \%$ & 108 & $70.1 \%$ & 31.695 & $<0.001^{*}$ \\
\hline & Either b or c & 104 & $46.0 \%$ & 38 & $24.7 \%$ & & \\
\hline & Yes & 147 & $65.0 \%$ & 93 & $60.4 \%$ & & \\
\hline Donning PPE: gloves, mask / respirator, goggles / face & No & 37 & $16.4 \%$ & 47 & $30.5 \%$ & 14.208 & $0.001^{*}$ \\
\hline & Don't know & 42 & $18.6 \%$ & 14 & $9.1 \%$ & & \\
\hline & True & 86 & $38.1 \%$ & 75 & $48.7 \%$ & & \\
\hline Doffing PPE: Gown, Gloves, Mask / respirator, Goggles & False & 74 & $32.7 \%$ & 57 & $37.0 \%$ & 11.737 & $0.003^{*}$ \\
\hline & Don't know & 66 & $29.2 \%$ & 22 & $14.3 \%$ & & \\
\hline Do you think the use of hand instrumentation along & Yes & 64 & $28.3 \%$ & 89 & $57.8 \%$ & & \\
\hline with the use of dental dam and high-speed suction can & No & 43 & $19.0 \%$ & 38 & $24.7 \%$ & 50.538 & $<0.001^{*}$ \\
\hline significantly minimize the spread of COVID-19? & Don't know & 119 & $52.7 \%$ & 27 & $17.5 \%$ & & \\
\hline & Yes & 116 & $51.3 \%$ & 111 & $72.1 \%$ & & \\
\hline Screening for dental emergencies using Tele-dentistry & No & 13 & $5.8 \%$ & 6 & $3.9 \%$ & 16.505 & $<0.001^{*}$ \\
\hline & Don't know & 97 & $42.9 \%$ & 37 & $24.0 \%$ & & \\
\hline If a patient reports with a travel history and symptoms & Yes & 133 & $58.8 \%$ & 79 & $51.3 \%$ & & \\
\hline of COVID-19, will you treat him / her according to & No & 47 & $20.8 \%$ & 49 & $31.8 \%$ & 5.922 & 0.06 \\
\hline triage? & Don't know & 46 & $20.4 \%$ & 26 & $16.9 \%$ & & \\
\hline & Yes & 210 & $92.9 \%$ & 151 & $98.1 \%$ & & \\
\hline $\begin{array}{l}\text { Will you report suspected cases to the concerned staff } \\
\text { and Head of Institution? }\end{array}$ & No & 2 & $0.9 \%$ & 1 & $0.6 \%$ & 5.533 & 0.06 \\
\hline & Don't know & 14 & $6.2 \%$ & 2 & $1.3 \%$ & & \\
\hline
\end{tabular}

About $40.3 \%(\mathrm{~N}=153)$ of them responded that covid-19 virus can survive hands, surfaces or objects when came in contact with infected saliva before 9 days. (Table 2); $39.4 \%$ (N = 89) were the pre-clinical and $41.6 \%(\mathrm{~N}=64)$ were the clinical students (P - 0.04) (Table 3) (Graph 1).

Majority of them $(82.6 \%, \mathrm{~N}=314)$ responded that a preoperative antimicrobial mouth rinse was recommended for a dental practice (Table - 2); $74.34 \%(\mathrm{~N}=168)$ were pre-clinic and $94.8 \%(\mathrm{~N}=146)$ were clinical students $(\mathrm{P}<0.001)$ (Table 3) (Graph- 2) and about $52.9 \%(\mathrm{~N}=201)$ of the total participants responded Chlorhexidine was currently recommended for use (Table -2$)$, among them $41.2 \%(\mathrm{~N}=93)$ were pre-clinical and $70.1 \%(\mathrm{~N}=108)$ were clinical students $(\mathrm{P}<0.001)$ (Table 3). 


\section{Jemds.com}

Original Research Article

About $22.1 \%(\mathrm{~N}=84)$ of the participants responded that the correct sequence of donning Personal protective equipment (PPE) was not the following: gloves, mask / respirator, goggles / face shield, gown (Table -2); $16.4 \%(\mathrm{~N}=$ $37)$ and $30.5 \%(\mathrm{~N}=47)$ were pre-clinical and clinical students respectively (P - 0.001) (Table 3) (Graph-2). About $34.5 \%$ (N
=131) of them responded that the doffing sequence of the PPE was not correct as mentioned: Gown, Gloves, Mask / respirator, Goggles / Face shield (Table -2); $32.7 \%(\mathrm{~N}=74)$ of them were pre-clinical and $37 \%(\mathrm{~N}=57)$ were clinical students (P - 0.003) (Table 3) (Graph 3).
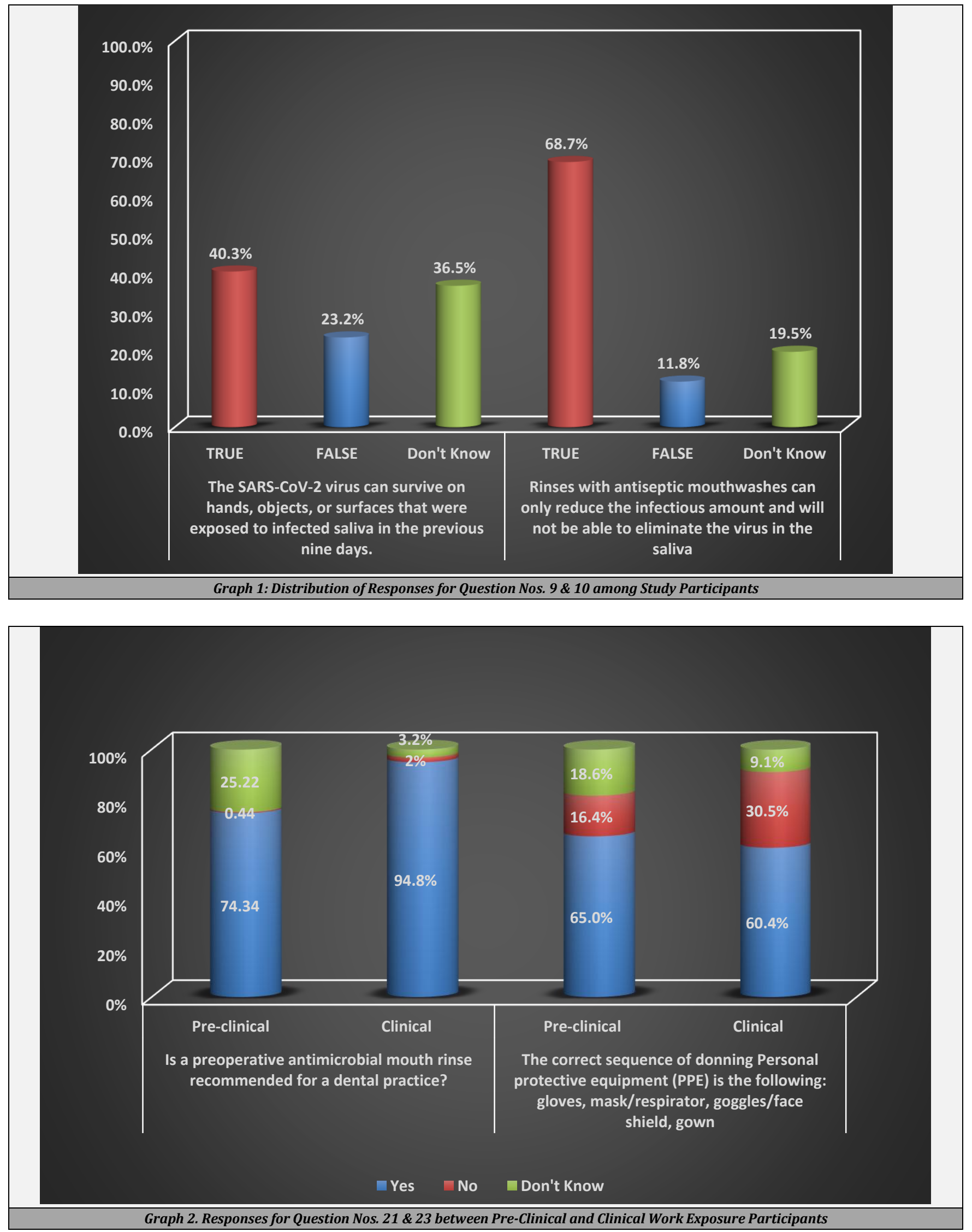


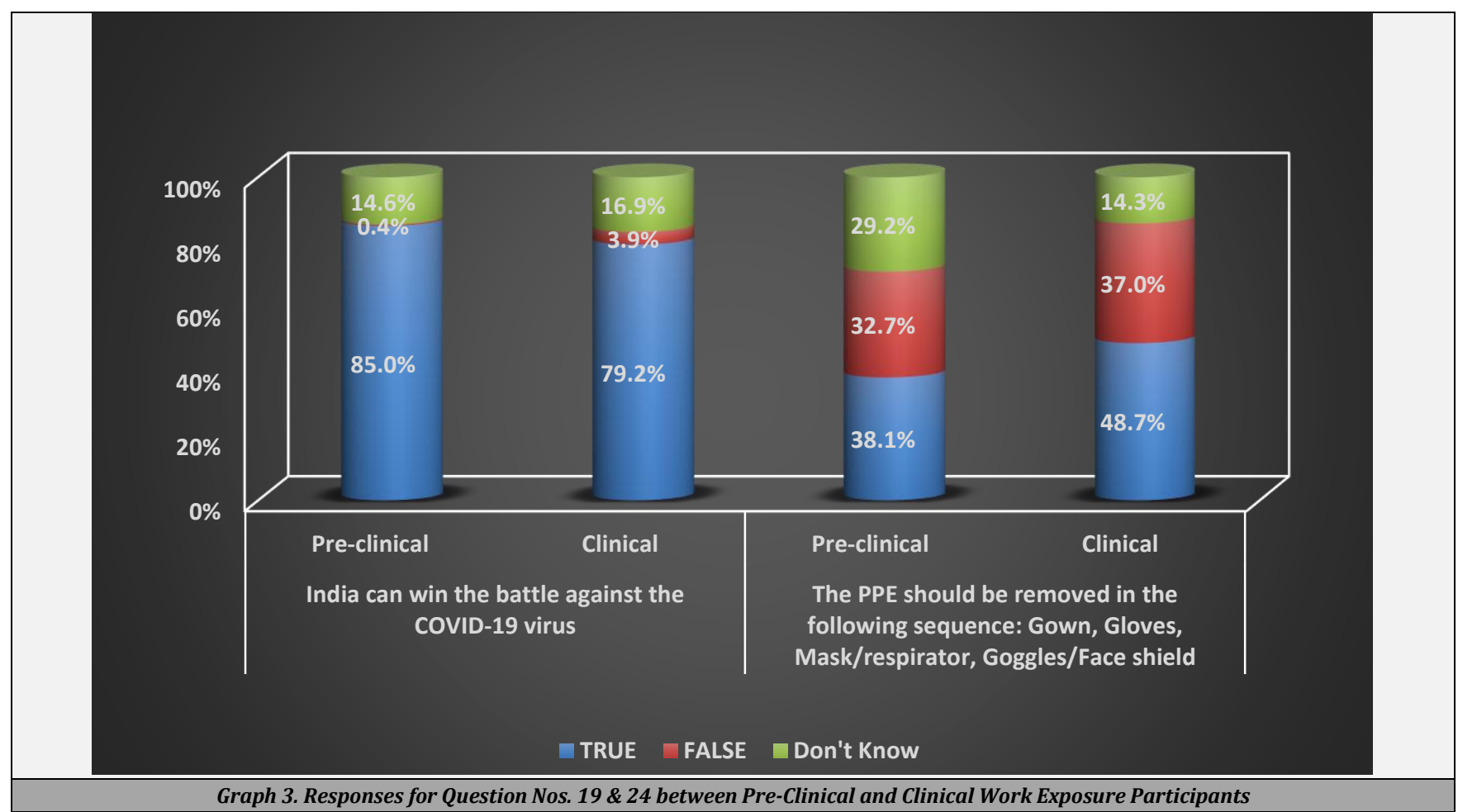

About $40.3 \%(\mathrm{~N}=153)$ of the participants thought that the use of hand instrumentation along with the use of dental dam and high-speed suction could significantly minimize the spread of COVID-19 (Table-2); $28.3 \%(\mathrm{~N}=64)$ and $57.8 \%(\mathrm{~N}$ = 89) of them were pre-clinical and clinical students respectively $(\mathrm{P}<0.001)$ (Table 3 ). A response rate of $59.7 \%$ $(\mathrm{N}=227)$ thought that screening for dental emergencies using Tele-dentistry or other methods minimized the disease transmission risk of COVID-19 (Table 2); $51.3 \%(\mathrm{~N}=116)$ were the pre-clinical and $72.2 \%(\mathrm{~N}=111)$ were clinical students $(\mathrm{P}<0.001)$ (Table 3$)$.

\section{DISCUSSION}

This descriptive online cross-sectional survey was conducted among 380 dental students of a tertiary Dental Care Hospital, to assess the perception about COVID-19; about $59.5 \%$ and $40.5 \%$ were pre-clinical students and clinical students respectively. In the present study, the correct response rate about the mode of transmission was high (96.3\%); however, awareness about the spread through airborne route of COVID19 was relatively low among pre-clinical and clinical students (59-66.2\%). It supports the findings of the studies done in different parts of the world. ${ }^{3-11}$ Contrarily, low knowledge about the mode of transmission was found in the studies done in UAE (2020) (39\%).

In the present study, majority of the participants (90\%) were aware of the main clinical symptoms of COVID-19. Similar results were found in the studies done in different parts of the world;5-8,11-15 whereas the findings were contrary to the studies of PAN-India (2020) $(58.8 \%)^{4}$ and Iran (2020) ${ }^{16}$ (47.5\%).

Majority of the participants (90.3\%) of the current study were aware of the fact that COVID-19 could be spread even in the pre-symptomatic stage from an infected patient, even through saliva. It was reported that live viruses were present in the saliva of infected individuals by viral culture method. ${ }^{17}$

In the present study most of the study population (86.1\%) were knowing that all the surfaces, chairs, magazines, doors of the clinic and the waiting area that come into contact with the dentists and patients must be considered "potentially infected", whereas only $50.8 \%$ of them were aware of the fact that SARS-CoV-2 remained longer on steel instruments. Similar findings were found in a study done in Lebanon (2020); majority (91.1\%) of them knew that COVID-19 could persist on surfaces for several days. ${ }^{7}$ As Corona virus can survive in aerosol and inanimate surfaces at room temperature for several days, clinical assistants should make sure to disinfect those surfaces. ${ }^{18}$

The dental healthcare professionals (DHPs), due the nature of treatment and high chances of coming in contact with body fluids like saliva and blood, face the highest risk of getting COVID-19 virus infection ${ }^{6}$ and this was supported by majority $(86.6 \%)$ of the respondents of the current study, which was similar to the PAN-Indian study (87 \%) ${ }^{11}$ and was supported by an article published in New Year Times. ${ }^{19}$

Majority of the participants of the current study reported that they followed hand hygiene practices like hand washing for at least 2 minutes (90.8\%) and using hand sanitizers which contained 60 - $95 \%$ alcohol (73.9\%); supportive literature findings were reported in many studies.3,4,6-8 Majority of the respondents (95.3\%) were aware that there was no effective cure for COVID-19, but isolation, early symptomatic and supportive treatment could help most patients recover from the infection; similar to the Mumbai study $(2020)^{3}(93.7 \%)$, Jordan study $(2020)^{13}$ (78.9\%), and China (2020) ${ }^{14}$ (94\%). In contrary to this, the findings of Tamil Nadu study (2020); $39.85 \%$ of the participants thought that the present most effective strategy in controlling COVID-19 was containment and mitigation. ${ }^{10}$

The overall case fatality rate of COVID-19 is $2.3 \%$ in China according to the empirical clinical data, explains much lower 
than that of SARS (9.5\%), MERS (34.4\%), H7N9 (39.0\%) ${ }^{14}$ and NIPAH (40 - $75 \%){ }^{20}$ In the present study, only $28.2 \%$ of the participants were not knowing whether COVID-19 was fatal than NIPAH virus infection, among them preclinical dental students were the most ( $35 \%$ ). Most of the respondents (82.6\%) of the current study had an attitude that India could win the battle against the COVID-19; similar to the results of the Chinese study (2020) ${ }^{14}(97.1 \%)$. In the present study, most of the participants (96.8\%) had an attitude to increase the awareness of COVID-19 to avoid social stigma regarding the same, as oral healthcare professionals; similar to the results of Jharkhand study (85\%) $(2020)^{6}$ and Jordan study (2020) $(67.7 \%)^{5}$

A pre-procedural mouth rinse would be most useful in the dental cases when rubber dam cannot be used. A preoperational mouth wash containing oxidative agents such as 1 $\%$ hydrogen peroxide or $0.2 \%$ povidone is recommended, as 2019-nCoV is vulnerable to oxidation and thus reducing the salivary load of oral microbes, including potential 2019-nCoV carriage. ${ }^{1}$ In the current study, only a few participants (37.4 $\%$ ) recommended pre-operational mouth rinses either $1 \%$ hydrogen peroxide or $0.2 \%$ povidone; high response rate was given by pre-clinical dental students, the response rate was similar in the Karnataka study (2020) ${ }^{15}$ (11-17 \%) and Tamil Nadu study (2020) (43 - 57 \%). ${ }^{10}$

Likewise, in the Jharkhand study (2020), for a question "Do you think a preoperational antimicrobial mouth rinse with 0.2 $\%$ Chlorhexidine, $1 \%$ hydrogen peroxide or $0.2 \%$ Povidoneiodine reduces the salivary load of COVID-19", majority of the participants (58.3\%) were not sure about this. ${ }^{6}$

When asked about the sequence of donning and doffing Personal Protective Equipment (PPE) in the current study, only $22.1 \%$ of the participants responded the mentioned sequence as wrong; most of them (37\%) were clinical dental students. This implies the sensitization about the importance of PPE in dental practice during COVID-19 among the dental students. Contrary results were found in the Jharkhand study $(2020)^{6}(76.7 \%)$ and in Lebanon study (2020) (64.8\%); more than half of the participants were aware of the donning and doffing sequence of PPE.

Dentists should minimize the utilization of ultrasonic instruments, high -speed hand pieces, and three-way syringes to cut back the chance of generating contaminated aerosols. ${ }^{18}$ In the present study, only $40.3 \%$ agreed that the use of hand instrumentation along with dental dam and high-speed suction can significantly minimize the spread of COVID-19; among them $57.8 \%$ were clinical dental students; similar to the Jharkhand study $(2020)^{6}(70.7 \%)$ and the study done among Indian dentists (2020)11 (73.7\%).

Tele-dentistry will be of great assistance within the current pandemic situation. ${ }^{21}$ The dentist has the whole right of educating and informing the patients through tele-screening with the help of applications available on the digital platform. ${ }^{22}$ More than half of the present study population (59.7\%), agreed the fact that screening for dental emergencies using tele-dentistry or other methods, minimizes the disease transmission, which was supported by the PANIndian study (2020) (46.3\%). ${ }^{11}$

In the current study, more than half of the participants $(55.8 \%, N=212)$ were ready to treat patients with a travel history according to the triage, thus recording the travel history as crucial for dental treatment during the pandemic. Triaging is the process of determining the priority of patients' treatment needs based on the severity of their condition. ${ }^{30}$ Supportive findings were found in the study conducted among Indian dentists $(2020)^{4} ; 93.8 \%$ of the respondents were aware of the critical importance of ascertaining the recent travel history of the patient. The COVID-19 pandemic has now spread to more than 200 countries and hence the travel history of a patient is crucial in determining his / her risk status. ${ }^{4}$ Majority of the participants (95\%) of the present study agreed to report the suspected cases to the concerned staff and Head of the Institution; which was similar to the findings of the Jordan study (2020) (58.2\%). ${ }^{5}$

With the reopening of colleges and hostels in Karnataka, Bengaluru's local civic body, the Bruhrat Mahanagara Palike (BBMP) has deployed the mobile swab collection teams in colleges and higher education institutions across the city, including our institution. Adequate measures were taken to sensitize about the guidelines and standard operating procedure issued by the state government and were followed in the institution.

\section{CONCLUSIONS}

Overall perception about COVID-19 among clinical dental students was slightly higher when compared with pre-clinical students. Open communication between students, teachers, and administrative staff would enhance mutual trust and facilitate adequate cooperation. With the increased knowledge of viral features, epidemiologic characteristics, clinical spectrum, and treatment, efficient strategies must be employed to stop and control the spread of COVID-19. As a result, posting visual alert icons such as signs and posters at the doorway and in strategic places to issue patients with instructions (in appropriate languages) about hand hygiene, respiratory hygiene, and cough etiquette have been implemented according to guidelines of the National Accreditation Board for Hospitals \& Healthcare Providers (NABH). The infection prevention and control strategies that should be adopted were communicated through online sessions during the lock down and reinforced in the offline classes after the resumption of regular college for students in the campus.

Data sharing statement provided by the authors is available with the full text of this article at jemds.com.

Financial or other competing interests: None.

Disclosure forms provided by the authors are available with the full text of this article at jemds.com.

\section{REFERENCES}

[1] Peng X, Xu X, Li Y, et al. Transmission routes of 2019-nCoV and controls in dental practice. International Journal of Oral Science 2020;12(1):1-6.

[2] To KKW, Tsang OTY, Leung WS, et al. Temporal profiles of viral load in posterior oropharyngeal saliva samples and serum antibody responses during infection by SARS-CoV- 
2: an observational cohort study. Lancet Infect Dis 2020;20(5):565-74.

[3] Modi PD, Nair G, Uppe A, et al. COVID-19 awareness among healthcare students and professionals in mumbai metropolitan region: a questionnaire-based survey. Cureus 2020;12(4):e7514.

[4] Kinariwala N, Samaranayake L, Perera I, et al. Knowledge, awareness and perceptions of coronavirus disease 2019 (COVID-19) in a cohort of Indian dental professionals: a questionnaire-based study. Preprints 2020:2020050442.

[5] Khader Y, Al Nsour M, Al-Batayneh OB, et al. Dentists' awareness, perception and attitude regarding COVID-19 and infection control: cross-sectional study among Jordanian dentists. JMIR Public Health Surveill 2020;6(2):e18798.

[6] Ahuja A, Razi MA, Qamar S. Assesment of knowledge and awareness regarding novel coronavirus (COVID-19) among dental professionals of Hazaribag District, Jharkhand, India. IP International Journal of Periodontology and Implantology 2020;5(2):78-86.

[7] Nasser Z, Fares Y, Daoud R, et al. Assessment of knowledge and practice of dentists towards coronavirus disease (COVID-19): a cross-sectional survey from Lebanon. BMC Oral Health 2020;20(1):281.

[8] Shahin SY, Bugshan AS, Almulhim KS, et al. Knowledge and attitude of dentists, dental auxiliaries and students regarding the COVID-19 pandemic in Saudi Arabia: a cross-sectional survey. BMC Oral Health 2020;20(1):363.

[9] Alharbi AJ, Alharbi KE, Kolarkodi SH, et al. Knowledge, attitude and preparations toward COVID-19 among dentists in Saudi Arabia: an online survey. International Journal of Medicine in Developing Countries 2020;4(11):1879-86.

[10] Gokulraj S, Mohan N, Raj BS, et al. Knowledge, awareness and perception towards covid-19 among dental students and professionals. International Journal of Advanced Science and Technology 2020;29(7):13596-609.

[11] Arora S, Saquib SA, Attar N, et al. Evaluation of knowledge and preparedness among Indian dentists during the current COVID-19 pandemic: a cross-sectional study. J Multidiscip Healthc 2020;13:841-54.
[12] Bhagavathula AS, Aldhaleei WA, Rahmani J, et al. Novel coronavirus (COVID-19) knowledge and perceptions: a survey on healthcare workers. medRxiv 2020.

[13] Alzoubi H, Alnawaiseh N, Asma'a Al-Mnayyis MA, et al. COVID-19-Knowledge, attitude and practice among medical and non-medical university students in Jordan. J Pure Appl Microbiol 2020;14(1):17-24.

[14] Zhong BL, Luo W, Li HM, et al. Knowledge, attitudes and practices towards COVID-19 among Chinese residents during the rapid rise period of the COVID-19 outbreak: a quick online cross-sectional survey. Int J Biol Sci 2020;16(10):1745-52.

[15] Pushpa SS, Janardhanan N, Bilichodmath S. Awareness, prevention and precaution among dentists regarding COVID-19. Journal of Health Sciences \& Research 2020;11(1):27-36.

[16] Nemati M, Ebrahimi B, Nemati F. Assessment of Iranian nurses' knowledge and anxiety towards COVID-19 during the current outbreak in Iran. Arch Clin Infect Dis 2020:e102848.

[17] To KKW, Tsang OTY, Yip CC, et al. Consistent detection of 2019 novel coronavirus in saliva. Clin Infect Dis 2020;71(15):841-3.

[18] Ather A, Patel B, Ruparel NB, et al. Coronavirus disease 19 (COVID-19): implications for clinical dental care. J Endod 2020;46(5):584-95.

[19] Gamio L. The workers who face the greatest coronavirus risk. New York Times 2020. https://www.nytimes.com/interactive/2020/03/15/bu siness/economy/coronavirus-worker-risk.html. Last accessed on 4 / 01 / 2020.

[20] WHO. Nipah virus 30 May 2018. https://www.who.int/news-room/factsheets/detail/nipah-virus\#: :text=Nipah $\% 20$ virus $\% 20$ infection \%20in \%20humans,at \%2040 \%25 \%20to $\% 2075 \% 25$. [Last accessed on 09 / 01 / 2021].

[21] Parimoo R, Singh B, Sharma D, et al. Coronavirus (COVID19): a dental surgeon's approach. Indian Journal of Dental Sciences 2021;13(1):50-3.

[22] Bhat PK, Nayana MM, Jayachandra MY. Containing the contagion-dental practice management post-COVID-19. Indian Journal of Dental Sciences 2020;13(1):54-9. 